\title{
PERBEDAAN TINGKAT PSYCHOLOGICAL WELL-BEING PADA IBU RUMAH TANGGA DENGAN IBU BEKERJA DI KABUPATEN GIANYAR
}

\author{
Ni Luh Komang Apsaryanthi, Made Diah Lestari \\ Program Studi Psikologi, Fakultas Kedokteran, Universitas Udayana \\ Komang_Apsaryanthi@yahoo.com
}

\begin{abstract}
Abstrak
Psychological well-being menunjukkan kondisi mental yang sehat yang ditandai dengan adanya kebahagiaan, mampu menghadapi tantangan atau masalah dan menggunakan potensi yang dimiliki dengan optimal. Psychological well-being penting dimiliki oleh para ibu. Peran ibu dapat dibedakan menjadi ibu rumah tangga dan ibu bekerja. Ibu rumah tangga akan fokus dan memiliki lebih banyak waktu dalam melaksanakan perannya dalam keluarga, sedangkan ibu bekerja harus mampu mengatur waktu untuk melaksanakan peran dalam keluarga dan juga peran dalam pekerjaannya. Perbedaan peran dan tanggung jawab antara ibu rumah tangga dan ibu bekerja dapat mempengaruhi psychological well-being. Penelitian ini bertujuan untuk mengetahui perbedaan tingkat psychological well-being pada ibu rumah tangga dengan ibu bekerja di Kabupaten Gianyar.

Subjek dalam penelitian ini berjumlah 200 individu yang terdiri dari 100 ibu rumah tangga dan 100 ibu bekerja. Metode pengambilan data menggunakan skala psychological well-being dengan koefisien Cronbach's Alpha $(a=0,877)$. Analisis statistik yang digunakan adalah Independent Sample T-Test. Hasil dari uji analisis data yaitu terdapat nilai signifikansi $\mathrm{p}=0,000(\mathrm{p}<0,05)$. Hasil dari penelitian ini menunjukkan bahwa terdapat perbedaan psychological well-being pada ibu rumah tangga dengan ibu bekerja di Kabupaten Gianyar.
\end{abstract}

Kata Kunci : psychological well-being, ibu rumah tangga, ibu bekerja

\begin{abstract}
Psychological well-being is a healthy mental condition characterized by happiness and use their optimum potential to face their challenges or problem. Psychological well-being is important to a mothers. Mother's role can be devided into housewife and working mother. Housewife will be focused and have more time to carry out their role in the family, while working mother should be able to set the time to carry out their role in the family and also their role in her work. Differences in roles and responsibilities between the housewifes and working mothers may affect the psychological wellbeing. This study aims to determine the differences levels of psychological well-being of the housewife and working mothers in Gianyar.
\end{abstract}

Subjects in this study were 200 individuals consist of 100 housewifes and 100 working mothers. Psychological wellbeing scale with a Cronbach's Alpha coefficient $(\mathrm{a}=0.877)$. Statistical analysis used Independent Sample T-Test. Result showed the significant value of $\mathrm{p}=0,000(\mathrm{p}<0,05)$. The result indicate there are differences in psychological well-being level's between housewife and working mothers in Gianyar.

Keywords: psychological well-being, housewife, working mother 


\section{LATAR BELAKANG}

Psychological well-being (kesejahteraan psikologis) merupakan suatu kondisi tertinggi yang dapat dicapai oleh individu. Psychological well-being adalah konsep keberfungsian optimal atau positif dari seseorang (Ryan \& Deci dalam Singh, Mohan, \& Anasseri, 2012). Psychological well-being dapat dicapai oleh individu melalui enam aspek antara lain menerima segala kekurangan dan kelebihan diri, mampu membina hubungan baik dengan orang lain, mandiri, menguasai lingkungan, memiliki tujuan hidup, dan terus mengembangkan potensi yang ada (Ryff, 1989). Psychological well-being penting untuk dicapai oleh kaum perempuan terlebih lagi yang memiliki peran sebagai ibu. Psychological well-being menggambarkan keadaan mental yang sehat yang mempengaruhi aspek-aspek lain dalam kehidupan. Sebagai seorang ibu, sejahtera secara psikologis akan mempengaruhi keyakinan ibu dalam mengasuh dan mendidik sehingga dapat meningkatkan perkembangan positif dari anak-anaknya. Hal ini sejalan dengan penelitian yang dilakukan oleh Irawati (2012) bahwa psychological well-being mempengaruhi parenting self-efficacy.

Dapat mencapai psychological well-being merupakan harapan semua individu, tak terkecuali para kaum perempuan yang memiliki peran sebagai ibu rumah tangga ataupun ibu bekerja di Kabupaten Gianyar. Kabupaten Gianyar adalah salah satu dari 9 Kabupaten/Kota di Bali yang kaya akan nilai adat istiadat (Atmaja \& Virnayanthi, 2010). Adat istiadat tercantum dalam awig-awig. Awig-awig memiliki arti suatu ketentuan yang mengatur tata krama pergaulan hidup dalam masyarakat untuk mewujudkan tata kehidupan yang harmonis di masyarakat (Surpha, 2002). Adat istiadat di Kabupten Gianyar mengikat para ibu untuk ikut terlibat dalam kegiatan adat seperti upacara keagamaan. Apabila ibu tidak melaksanakan kewajiban tersebut maka akan mendapatkan sanksi. Sanksi tersebut dapat berupa denda maupun diasingkan dari orang-orang sekitar sehingga dapat berdampak terhadap psikologis individu (Surpha, 2002).

Kaum perempuan di Gianyar yang berperan sebagai ibu rumah tangga akan fokus dan memiliki lebih banyak waktu dalam menjalankan peran dalam keluarga dan melaksanakan tugas-tugas adat. Memilih untuk menjadi ibu rumah tangga merupakan kebahagiaan sendiri bagi individu yang bersangkutan, karena peran sebagai ibu rumah tangga memiliki banyak dampak positif. Beberapa dampak positif dari peran ibu rumah tangga adalah ibu rumah tangga memiliki waktu lebih banyak di rumah sehingga tidak akan kehilangan saatsaat penting pertumbuhan anak dan dapat menjadi role model yang baik bagi anak. Peran tersebut tidak bisa tergantikan oleh pengasuh ataupun siaran televisi. Para ibu juga dapat mendampangi anak-anak saat masa-masa sulit mereka, yakni menurut U.S. Departement of Human Service anak-anak yang tidak didampingi orangtua dalam waktu lebih lama cenderung mengalami peningkatan masalah perilaku (dalam Harmandini, 2012). Dampak positif lainnya ialah ibu rumah tangga dapat menghemat energi sehingga memiliki kondisi yang prima saat menemani anak-anak. Meskipun ibu rumah tangga dapat mengalami stres, namun keuntungan lainnya yang diperoleh dari peran menjadi ibu rumah tangga adalah tidak akan mengalami stres yang disebabkan oleh tuntutan untuk membagi peran antara karir dan rumah tangga, karena berbagi peran tersebut bukanlah pekerjaan mudah (Harmandini, 2012).

Seiring dengan perkembangan zaman, mulai tampak adanya pergeseran peran para perempuan. Dahulu, perempuan berpikir menjadi ibu rumah tangga sepenuhnya, namun sekarang ada kecenderungan untuk memiliki sedikit anak dan bisa menentukan kapan memiliki seorang anak. Hal ini dikarenakan mengontrol kelahiran merupakan hal yang umum dilakukan. Melahirkan sedikit anak dan berkurangnya tuntutan untuk merawat anak memberikan peluang bagi kaum perempuan untuk melakukan kegiatan yang lain (Santrock, 2002). Kehidupan modern dan dalam era pembangunan saat ini, banyak perempuan yang tidak puas jika hanya di rumah menjalankan tugas-tugas rumah tangga. Banyak kaum perempuan yang telah memasuki dunia kerja.

Adanya adat istiadat yang mengikat para perempuan di Kabupaten Gianyar, tidak menjadi penghalang bagi para perempuan untuk memiliki pekerjaan di luar kegiatan domestik. Jumlah perempuan bekerja di Kabupaten Gianyar sebanyak 118.762 orang. Jumlah perempuan bekerja tertinggi berada di Kota Denpasar dengan jumlah 189.782 orang, diikuti dengan Kabupaten Buleleng dengan jumlah 157.859 orang, Kabupaten Badung dengan jumlah 133.463 orang (Badan Pusat Statistik Provinsi Bali, 2011). Meskipun jumlah perempuan bekerja tertinggi berada di Kota Denpasar, namun Kabupaten Gianyar memiliki jumlah penduduk pendatang perempuan yang tergolong sedikit dengan jumlah penduduk pendatang adalah 7.287 orang. Jumlah tersebut sangat berbeda jauh jika dibandingkan dengan Kota Denpasar yang memiliki jumlah penduduk pendatang perempuan 24.898 orang dan juga Kabupaten Badung 24.766 orang (Badan Pusat Statistik Provinsi Bali (2010). Semakin sedikit jumlah penduduk pendatang maka dominan proporsi tenaga kerja di wilayah bersangkutan adalah tenaga kerja asli wilayah tersebut. Data tersebut menunjukkan bahwa meskipun di Kabupaten Gianyar memiliki adat istiadat yang mengharuskan perempuan memiliki peran lebih, namun jumlah penduduk perempuan di Gianyar yang bekerja tergolong tinggi.

Ibu bekerja di Kabupaten Gianyar memiliki tugas dan tanggungjawab yang lebih besar dibandingkan ibu rumah tangga. Ibu bekerja dituntut mampu mengatur waktu untuk melaksanakan tugas rumah tangga, tugas dalam pekerjaan, dan tugas adat. Adanya tiga peran yang harus dijalani membuat ibu bekerja memiliki waktu yang terbatas saat berada di rumah. 
Menurut Santrock (2002) peran yang dijalankan oleh ibu bekerja dapat menimbulkan stres yang disebabkan oleh adanya tuntutan waktu dan tenaga tambahan, pembagian waktu untuk kelurga dan karir, konflik antara peran pekerjaan dan peran keluarga, persaingan kompetitif antara suami dan istri, serta yang menjadi permasalahan penting adalah apakah perhatian terhadap kebutuhan anak sudah terpenuhi dengan baik atau belum. Lubis (2013) juga mengungkapkan bahwa ibu yang bekerja cenderung dapat mempengaruhi keharmonisan keluarga. Hal tersebut dikarenakan kesibukan aktivitas yang berlebihan cenderung membuat seorang ibu tidak mempunyai banyak waktu untuk keluarga dan pusat perhatian ibu yang lebih mengarah pada kesuksesan karier dapat membuat ibu menjadi menelantarkan peran sebagai istri dan juga sebagai ibu.

Ibu bekerja sering diasumsikan memiliki perasaan bersalah karena tidak memiliki waktu bersama anak-anak, namun sebuah penelitian menunjukkan hasil yang berbeda. Penelitian terbaru dari situs Parenting Mumsnet (dalam Febrida, 2014) yang dilakukan pada 900 ibu menunjukkan bahwa hampir setengahnya yakni sebesar $48 \%$ subjek mengatakan memiliki pekerjaan yang dibayar membuat ibu lebih bahagia. Sebanyak $52 \%$ subjek mengatakan tinggal di rumah lebih berat dibandingkan pergi bekerja. Hanya $13 \%$ ibu bekerja yang merasa bersalah menghabiskan waktunya jauh dari rumah. Hal ini dikarenakan ibu bekerja yang memiliki waktu terbatas akan memiliki energi yang lebih saat ibu dapat bersama dengan anak-anaknya. Penelitian tersebut juga mengungkapkan ibu rumah tangga yang tinggal di rumah merasa tidak dihargai oleh orang lain dan merasa khawatir anak-anaknya akan menjadi manja apabila tetap berada di rumah. Hal yang serupa diungkapkan oleh Barnhouse (1994) bahwa yang lebih penting dalam menjalin hubungan antara ibu dan anak adalah kualitas waktu yang digunakan saat bersama anak-anak bukan kuantitasnya.

Penelitian yang lain menunjukkan hasil yang sama yakni berdasarkan penelitian yang dilakukan kepada 60.799 perempuan menunjukkan bahwa ibu yang tidak bekerja atau ibu rumah tangga mengalami emosi negatif lebih banyak seperti khawatir, sedih, marah, stres, dan depresi, dibandingkan ibu yang bekerja. Penelitian ini menunjukkan $41 \%$ ibu rumah tangga mengalami kecemasan, sementara hanya $34 \%$ dari ibu bekerja mengalami perasaan serupa. Stres juga terjadi pada $50 \%$ ibu rumah tangga, dan $48 \%$ ibu bekerja. Kemarahan ditemukan pada $19 \%$ ibu rumah tangga dan $14 \%$ ibu bekerja. Penelitian ini juga mengatakan bahwa ibu rumah tangga memungkinkan mengalami depresi dibanding ibu bekerja, hal ini dikarenakan ibu rumah tangga cenderung sulit mengungkapkan kebahagiaan, dan lebih sedikit tertawa atau tersenyum, serta mempelajari hal yang menarik (Handayani \& Abbdinnah, 2012). Hal serupa diungkapkan oleh Santrock (2002) yakni keuntungan lainnya menjadi ibu bekerja adalah selain dapat meningkatkan perekonomian keluarga, juga berkontribusi pada hubungan yang lebih setara antara suami dan istri, dan meningkatkan rasa harga diri bagi perempuan karena dengan bekerja dapat menambah pengetahuan sehingga ibu diberi kesempatan untuk berpartisipasi dalam mengambil keputusan dalam keluarga.

Memilih menjadi seorang ibu rumah tangga maupun ibu bekerja akan memiliki kelebihan dan juga kekurangan yang harus dihadapi oleh para kaum perempuan. Kelebihan menjadi ibu rumah tangga adalah ibu dapat memiliki lebih banyak waktu untuk keluarga dan tidak merasakan stres akibat konflik peran, sedangkan kekurangan yang dialami oleh ibu rumah tangga adalah kecenderungan yang lebih tinggi untuk menghadapi emosi negatif seperti seperti khawatir, sedih, marah, stres, dan depresi dibandingkan ibu yang bekerja. Kelebihan ibu bekerja adalah menjadi lebih mandiri, hubungan yang setara dengan suami, dan juga meningkatkan harga diri, sedangkan kekurangannya ialah ibu bekerja memiliki kecenderungan untuk memiliki konflik peran. Adanya perbedaan kelebihan dan kekurangan yang dijalankan oleh kaum perempuan baik yang berperan sebagai ibu rumah tangga dan ibu bekerja akan berdampak pada psychological wellbeing yang telah dicapai oleh ibu. Berdasarkan uraian di atas, maka peneliti ingin mengetahui apakah ada perbedaan tingkat psychological well-being pada ibu rumah tangga dengan ibu bekerja di Kabupaten Gianyar.

\section{METODE}

\section{Variabel dan Definisi Operasional}

Variabel bebas dalam penelitian ini adalah status bekerja ibu sedangkan variabel terikat dalam penelitian ini ialah psychological well-being. Adapun definisi operasional dari masing-masing variabel penelitian ialah sebagai berikut:

1. Psychological well-being adalah kondisi individu yang ditandai dengan adanya kebahagiaan, mampu tumbuh dan berkembang, serta menunjukkan potensinya secara optimal, yang dapat diketahui dari adanya sikap penerimaan diri, memiliki hubungan positif dengan orang lain, otonomi, penguasaan lingkungan, memiliki tujuan hidup, serta pertumbuhan pribadi. Psychological well-being akan diukur dengan menggunakan skala yang peneliti susun sendiri berdasarkan teori atau pernyataan yang diungkapkan oleh Carol Ryff(dalam Singh, dkk, 2012).

2. Status bekerja ibu yang dimaksud dalam penelitian ini adalah keadaan atau kedudukan ibu yakni sebagai ibu rumah tangga atau ibu bekerja. Ibu rumah tangga adalah perempuan yang lebih banyak menghabiskan waktunya dirumah untuk melakukan kegiatan rumah tangga termasuk memelihara, mendidik, dan mengasuh anakanak tanpa terikat pekerjaan di luar kegiatan rumah 
tangga. Ibu yang bekerja adalah seorang perempuan, yang melakukan kegiatan secara teratur, yang selain mengurus rumah tangga juga memiliki tanggung jawab atau terikat dengan pekerjaan di luar kegiatan rumah tangga, baik bekerja di instasi negeri, swasta, atau kegiatan wiraswasta untuk memperoleh penghasilan sendiri. Pengukuran pada variabel ini dilakukan dengan pengkategorisasian status bekerja ibu yang dicantumkan dalam lembar kuesioner.

\section{Responden}

Populasi dalam penelitian ini adalah ibu rumah tangga dan ibu bekerja yang berada di wilayah Kabupaten Gianyar. Sampel yang digunakan dalam penelitian ini adalah sebagian dari ibu rumah tangga dan ibu bekerja yang berada di wilayah Kabupaten Gianyar yang memiliki karakteristik antara lain berusia 18-40 tahun, tingkat pendidikan minimal SMA/SMK sederajat, dan asih memiliki suami dan minimal memiliki satu anak. Teknik pengambilan sampel yang digunakan pada penelitian ini adalah Area Sampling. Pengambilan sampel dilakukan dengan dua kali tahapan (two stage sampling), yaitu tahap pertama membagi populasi atas kelompok berdasarkan area, kemudian memilih area secara acak untuk dijadikan primary sampling unit (PSU). Jumlah responden dalam penelitian ini adalah100 orang ibu rumah tangga dan 100 orang ibu bekerja.

\section{Tempat Penelitian}

Proses pengambilan sampel dilakukan 8 wilayah dusun/banjar di Kecamatan Blahbatuh, Kabupaten Gianyar. Penelitian dilaksanakan pada bulan April sampai dengan Mei 2015.

\section{Alat Ukur}

Alat ukur yang digunakan dalam penelitian ini adalah skala psychological well-being. Skala psychological well-being yang digunakan dalam penelitian ini terdiri dari enam aspek untuk mengukur psychological well-being pada ibu rumah tangga dan ibu bekerja yang peneliti susun berdasarkan teori atau pernyataan yang diungkapkan oleh Carol Ryff (dalam Singh, Mohan, \& Anasseri, 2012) dengan menggunakan model skala likert. Skala psychological well-being terdiri 29 aitem. Skala disusun dalam bentuk pernyataan favorbale dan unfavourable yang diberi skor dari 1 sampai 4. Pada pernyataan dalam aitem favorable jawaban sangat setuju (SS) diberi skor 4, setuju (S) diberi skor 3, tidak setuju (TS) diberi skor 2, dan sangat tidak setuju (STS) diberi skor 1. Sedangkan dalam pernyataan dalam aitem unfavorable jawaban sangat setuju (SS) diberi skor 1, setuju (S) diberi skor 2, tidak setuju (TS) diberi skor 3, dan sangat tidak setuju (STS) diberi skor 4.

Pada pengujian validitas skala psychological well-being koefisien korelasi item-total berkisar dari 0,256 sampai dengan
0,648. Hasil reliabilitas skala psychological well-being dengan menggunakan Cronbach Alpha $(\alpha)$ adalah sebesar 0,877. Koefisien alpha sebesar 0,877 menunjukkan bahwa skala psychological well-being dapat mencerminkan $87,7 \%$ variasi skor subjek adalah skor murni. Hasil tersebut menunjukkan bahwa skala psychological well-being dapat digunakan untuk mengukur psychological well-being.

\section{Teknik Analisis Data}

Teknik analisis yang digunakan untuk dapat menguji hipotesis dalam penelitian ini adalah independent sample t-test. Tujuan penggunaan independent sample t-test adalah untuk mengetahui apakah ada perbedaan rata-rata (mean) antara dua populasi, dengan melihat rata-rata dua sampelnya. Analisis dilakukan dengan bantuan perangkat lunak SPSS versi 15.00. Sebelum melakukan analisis dengan independent sample t-test, peneliti melakukan uji normalitas dan uji homogenitias. Uji normalitas sebaran data pada penelitian ini menggunakan teknik Kolmogorov-Smirnov Goodnessof Fit Test dan uji homogenitas dalam penelitian ini dilakukan dengan menggunakan uji Levene's Test for Equality of Variances.

\section{HASIL PENELITIAN}

\section{Karakteristik Subjek}

Karakteristik subjek dalam penelitian terdiri dari 100 ibu rumah tangga dan ibu bekerja yang memiliki rentang usia 20 tahun sampai 40 tahun. Pada penelitian ini subjek yang memiliki pendidikan terakhir SMA sebanyak 123 orang, pendidikan terakhir diploma sebanyak 20 orang, dan pendidikan terakhir S1 sebanyak 54 orang, serta pendidikan terakhir S2 sebanyak 3 orang.

\section{Deskripsi Data Penelitian}

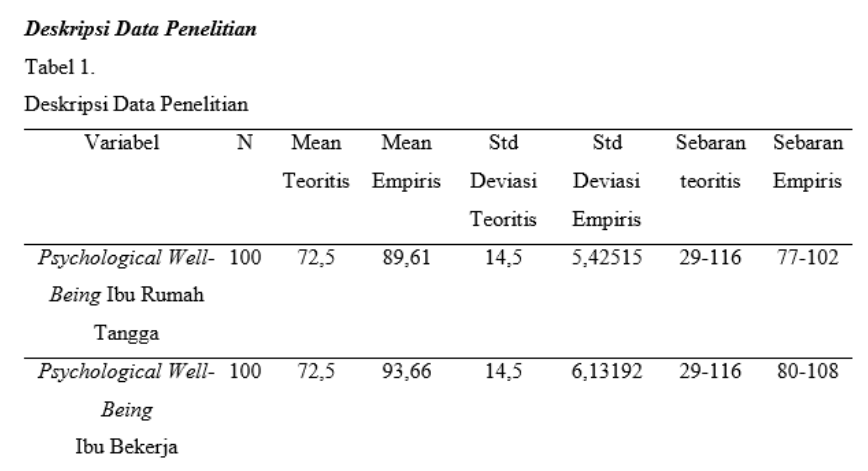

Berdasarkan tabel 1, terlihat bahwa terdapat perbedaan mean teoritis dengan mean empiris pada skala psychological well-being. Pada kelompok ibu rumah tangga dan ibu bekerja sama-sama menunjukkan bahwa nilai mean empiris lebih besar daripada mean teoritis. Pada tabel 1 juga dapat diketahui bahwa mean empiris ibu bekerja lebih tinggi dibandingkan ibu rumah tangga. 
Tabel 2.

Kategori Psychological Well-Being

\begin{tabular}{llcc}
\hline \multicolumn{1}{c}{ Rentang Nilai } & \multicolumn{1}{c}{ Kategori } & Ibu Rumah Tangga & Ibu Bekerja \\
\hline $\mathrm{X} \leq 50,75$ & Sangat Rendah & 0 & 0 \\
\hline $50,47<\mathrm{X} \leq 65,25$ & Rendah & 0 & 0 \\
\hline $65,25<\mathrm{X} \leq 79,75$ & Sedang & 4 & 0 \\
\hline $79,75<\mathrm{X} \leq 94,25$ & Tinggi & 73 & 54 \\
\hline $94,25<\mathrm{X}$ & Sangat Tinggi & 23 & 46 \\
\hline Jumlah & & 100 & 100
\end{tabular}

Berdasarkan tabel 2, dapat diketahui bahwa mayoritas ibu rumah tangga dan ibu bekerja termasuk dalam kategori skor tinggi, yakni ibu rumah tangga berjumlah 73 dan ibu bekerja berjumlah 54 orang. Pada kategori skor sangat tinggi, lebih banyak individu dari kelompok ibu bekerja yakni sebesar 46 orang, sedangkan individu dari kelompok ibu rumah tangga hanya berjumlah 23 orang.

\section{Uji Asumsi}

Tabel 3.

Uji Normalitas Variabel Penelitian

\begin{tabular}{ccc}
\hline Variabel & Kolmogorof-Smirnov (K-S) Z & Asymp. Sig. (2 tailed) \\
\hline Psychological Well-Being & 0,971 & 0,302
\end{tabular}

Berdasarkan tabel 3, dapat diketahui variabel psychological well-being memiliki nilai sebesar 0,971 dengan signifikansi sebesar 0,302 $(\mathrm{p}>0,05)$. Nilai tersebut menunjukkan bahwa data pada variabel psychological wellbeing memiliki distribusi yang normal.

Tabel 4.

Uji Homogenitas Variabel Penelitian

\begin{tabular}{ccc}
\hline Variabel & F & Signifikansi \\
\hline Psychological Well-Being & 1,003 & 0,318
\end{tabular}

Berdasarkan tabel 4, dapat diketahui variabel psychological well-being memiliki nilai $\mathrm{F}$ sebesar 1,003 dengan signifikansi sebesar 0,318 ( $>0,05)$. Nilai tersebut menunjukkan bahwa data pada variabel psychological wellbeing adalah data homogen.

Berdasarkan hasil uji normalitas uji dan homogenitas yang telah peneliti lakukan, maka dapat disimpulkan bahwa data penelitian ini berdistribusi normal dan data bersifat homogen, sehingga dapat dilanjutkan dengan melakukan uji independent sample t-test.

\section{Uji Hipotesis}

Pada penelitian ini akan dilakukan uji hipotesis dengan menggunakan uji independent sample t-test .

Tabel 5 .

Hasil analisis independent sample t-test

\begin{tabular}{cc}
\hline Variabel & Sig.(2-tailed) \\
& \\
\hline Psychological Well-Being & 0,000
\end{tabular}

Hasil analisis independent sample t-test menunjukkan bahwa nilai signifikansi sebesar $0,000(\mathrm{p}<0.05)$. Hal tersebut menunjukkan bahwa terdapat perbedaan tingkat psychological well-being yang signifikan pada dua kelompok subjek, yaitu kelompok ibu rumah tangga dengan ibu bekerja. Berdasarkan hasil analisis juga diketahui bahwa mean kelompok ibu rumah tangga adalah 89,61 dan mean kelompok ibu bekerja adalah 93,66. Hal ini menunjukkan bahwa mean kelompok ibu bekerja lebih tinggi daripada ibu rumah tangga.

\section{Analisis Data Tambahan}

Peneliti juga melakukan analisis tambahan untuk mengetahui perbedaan tingkat psychological well-being berdasarkan jumlah anak, yakni pada kelompok ibu yang memiliki 1-2 anak dengan kelompok ibu yang memiliki 3-4 anak. Hasil uji beda tersebut, dapat dilihat pada tabel 6 .

\begin{tabular}{lcccc} 
Tabel 6. \\
Uji Perbedaan Psychological Well Being & Berdasarkan Jumlah Anak & \\
\hline \multicolumn{5}{c}{} \\
Total & F & Sig. & Sig.(2-tailed) \\
\hline $\begin{array}{c}\text { Psychological } \\
\text { Well-Being }\end{array}$ & variances & .356 & .551 & 0,778 \\
& assumed & & &
\end{tabular}

Pada Tabel 6, hasil uji independent sample t test terlihat nilai $\mathrm{F}$ test untuk psychological well-being adalah 0.356 dengan probabilitas 0.551 ( $\mathrm{P}>0.05)$, maka data diasumsikan memiliki varians yang sama. Tabel 6 menunjukkan bahwa nilai signifikansi sebesar 0,778 ( $>$ >0.05). Hal tersebut menunjukkan bahwa tidak ada perbedaan perbedaan tingkat psychological well-being pada kelompok ibu yang memiliki 12 anak dengan kelompok ibu yang memiliki 3-4 anak.

Analisis tambahan juga dilakukan mengetahui perbedaan tingkat psychological well-being berdasarkan tingkat pendidikan, yakni pada kelompok ibu yang berpendidikan dasar (SMA/SMK sederajat) dengan kelompok ibu yang berpendidikan tinggi (diploma, S1, dan S2). Hasil uji beda tersebut, dapat dilihat pada tabel 7 .

Tabel 7.

Uji Perbedaan Psychological Well Being Berdasarkan Tingkat Pendidikan

\begin{tabular}{ccccc}
\hline & & $\mathrm{F}$ & Sig. & Sig.(2-tailed) \\
\hline Total & Equal & 2.354 & 0,127 & 0,112 \\
Psychological & variances & & & \\
Well-Being & assumed & & & \\
\hline
\end{tabular}

Pada Tabel 7, hasil uji independent sample t test terlihat nilai $\mathrm{F}$ test untuk psychological well-being adalah 2.354 dengan probabilitas 0,127 ( $>>0.05)$, maka data diasumsikan memiliki varians yang sama. Tabel 7 menunjukkan bahwa nilai signifikansi sebesar 0,112 ( $>$ >0.05). Hal tersebut menunjukkan bahwa tidak ada perbedaan tingkat psychological well-being pada kelompok ibu yang berpendidikan dasar (SMA/SMK sederajat) dengan kelompok ibu yang berpendidikan tinggi (diploma, S1, dan S2). 
Peneliti juga melakukan analisis tambahan untuk mengetahui perbedaan tingkat psychological well-being pada ibu yang usia pernikahan 1-10 tahun dengan ibu yang usia pernikahan 11-22 tahun. Hasil uji beda tersebut, dapat dilihat pada tabel 8 .

\begin{tabular}{|c|c|c|c|c|}
\hline \multicolumn{5}{|c|}{ Uji Perbedaan Psychological Well-Being Berdasarkan Usia Pernikahan } \\
\hline & & F & Sig. & Sig.(2-tailed) \\
\hline Total & Equal & 2.160 & 0,143 & 0,038 \\
\hline Psychological & variances & & & \\
\hline Well-Being & assumed & & & \\
\hline
\end{tabular}

Pada Tabel 8, hasil uji independent sample t test terlihat nilai $\mathrm{F}$ test untuk psychological well-being adalah 2.160 dengan probabilitas $0,143(\mathrm{P}>0.05)$, maka data diasumsikan memiliki varians yang sama. Tabel 16 menunjukkan bahwa nilai signifikansi sebesar $0,038 \quad(\mathrm{p}<0.05)$. Hal tersebut menunjukkan bahwa terdapat perbedaan tingkat psychological well-being pada kelompok ibu yang usia pernikahan 1-10 tahun dengan ibu yang usia pernikahan 11-22 tahun.

Tabel 9 .

Deskripsi mean dan standar deviasi berdasarkan usia pernikahan subjek

\begin{tabular}{ccccc}
\hline Usia Pernikahan & $\mathbf{N}$ & Mean & Standar Deviasi & Std. Error Mean \\
\hline $1-10$ & 112 & 90.84 & 6.406 & 0,605 \\
\hline $11-22$ & 88 & 92.65 & 5.612 & 0,598 \\
\hline
\end{tabular}

Berdasarkan tabel 9, diketahui bahwa kelompok subjek dengan usia pernikahan 1-10 memiliki mean sebesar 90.84 dengan standar deviasi sebesar 6,406. Pada kelompok subjek dengan usia pernikahan 11-22 memiliki mean sebesar 92,65 dengan standar deviasi sebesar 5,612. Maka dapat diketahui bahwa rata-rata tingkat psychological well-being berdasarkan usia pernikahan memiliki perbedaan yang signifikan, yakni kelompok ibu dengan usia pernikahan 1-10 tahun memiliki psychological well-being yang lebih tinggi dibandingkan dengan kelompok ibu dengan usia pernikahan 11-22 tahun

\section{PEMBAHASAN DAN KESIMPULAN}

Berdasarkan hasil analisis perbandingan dengan menggunakan independent samples $t$ test, didapat bahwa nilai signifikansi $\mathrm{p}$ adalah sebesar 0,000 ( $\mathrm{p}<0,05)$. Hal ini menunjukkan bahwa terdapat perbedaan tingkat psychological well-being pada ibu rumah tangga dengan ibu bekerja, atau dapat disimpulkan bahwa hipotesis alternatif (Ha) yang diajukan dalam penelitian ini diterima dan hipotesis nol (H0) ditolak.

Hasil analisis juga diketahui bahwa mean kelompok ibu rumah tangga adalah 89,61 dan mean kelompok ibu bekerja adalah 93,66. Hal ini menunjukkan bahwa kelompok ibu bekerja memiliki tingkat psychological well-being yang lebih tinggi dibandingkan dengan kelompok ibu rumah tangga. Psychological well-being adalah kondisi individu yang ditandai dengan adanya kebahagiaan, mampu menghadapi tantangan-tantangan dalam hidup, dan menggunakan kemampuan dengan optimal. Hal ini sesuai dengan pernyataan dari Ahrens, Ryff, dan Betz (dalam Matlin, 2012) bahwa kaum wanita yang bekerja merasa lebih bahagia dan memiliki penyesuaian diri yang lebih baik daripada wanita yang tidak bekerja. Wanita yang bekerja akan memiliki kesempatan untuk belajar dari berbagai situasi yang harus dihadapi, termasuk adanya tantangan-tantangan dalam pekerjaannya dan akan memperoleh kesenangan saat mampu mencapai tujuan jangka panjang dalam pekerjaan (Ahrens, Byff, Barnett, Hyde, \& Betz, dalam Matlin, 2012). Adanya proses belajar dalam menjalankan peran ganda pada ibu bekerja akan memengaruhi tingkat pertumbuhan pribadi dan kemampuan untuk mengatasi berbagai situasi atau tugas, baik tugas rumah tangga maupun pekerjaan juga akan memengaruhi tingkat penguasaan lingkungan. Kondisi ini membuat kaum ibu bekerja di Kabupaten Gianyar mampu mencapai tingkat psychological well-being yang tinggi.

Hasil kategorisasi skor skala psychological well-being menunjukkan bahwa tidak terdapat individu dari kelompok ibu rumah tangga maupun ibu bekerja yang memiliki skor sangat rendah dan skor rendah. Hasil kategorisasi skor juga menunjukkan bahwa ibu rumah tangga dan ibu bekerja samasama mayoritas termasuk dalam kategori tinggi, yakni terdapat $73 \mathrm{ibu}$ rumah tangga dan $54 \mathrm{ibu}$ bekerja. Hal ini menunjukkan bahwa ibu rumah tangga dan ibu bekerja samasama dapat mencapai tingkat psychological well-being yang baik. Hasil kategorisasi skor tersebut menunjukkan bahwa psychological well-being tidak hanya dipengaruhi oleh status bekerja ibu, namun juga dapat dipengaruhi oleh faktor-faktor lain yang tidak diteliti dalam penelitian ini. Faktor yang juga memengaruhi psychological well-being, yakni seperti budaya (Ryff, 1995). Bali, khusunya Kabupaten Gianyar memiliki budaya kolektivitas atau kebersamaan. Dalam budaya kolektivitas dikenal dengan adanya sifat saling membantu atau adanya dukungan sosial yang kuat. Dukungan sosial dapat memengaruhi psychological well-being (Green \& Shellenberger, Brannon \& Feist, dalam Compton, 2005). Dukungan sosial yang diberikan oleh orang-orang disekitar ibu dapat berupa bantuan dalam mengerjakan kegiatan sehari-hari ibu, maupun penghargaan terhadap para ibu. Adanya dukungan sosial ini membuat para ibu di Kabupaten Gianyar mampu melaksanakan peran domestik, publik, dan sosial sehingga dapat mencapai psychological well-being tergolong tinggi.

Meskipun hasil kategorisasi skor menunjukkan bahwa ibu rumah tangga dan ibu bekerja mayoritas sama-sama berada dalam kategori tinggi, namun kategori skor juga menunjukkan sebanyak 23 subjek dari kelompok ibu rumah tangga termasuk 
dalam kategori skor sangat tinggi, sedangkan pada ibu bekerja terdapat 46 subjek yang termasuk dalam kategori skor sangat tinggi. Kategorisasi tersebut menunjukkan lebih banyak ibu bekerja yang memiliki skor sangat tinggi dibandingkan ibu rumah tangga. Hal ini sesuai dengan pernyataan dari Betz, Cleveland, Rogers dan DeBoer (dalam Matlin, 2012) bahwa pekerjaan yang dimiliki oleh wanita mampu meningkatkan harga diri. Banyak kaum wanita bekerja melaporkan perasaan yang lebih tinggi dalam kompetensi, prestasi, dan kepuasan hidup dibandingkan wanita yang tidak bekerja. Hal ini juga didukung dengan penelitian yang dilakukan oleh Susanti (2012), bahwa semakin tinggi harga diri maka semakin tinggi pula psychological well-being pada wanita yang bekerja.

Saat kaum wanita memiliki anak, maka statusnya akan berubah menjadi orangtua. Masa menjadi orang tua disebut sebagai "masa krisis" karena memerlukan banyak perubahan perilaku, nilai, peran dan tanggung jawab yang lebih besar (Hurlock, 1980). Tanggung jawab juga akan semakin besar sebanding dengan jumlah anak yang dimiliki. Pada penelitian ini menunjukkan hal yang berbeda, yakni tidak ada perbedaan tingkat psychological well-being pada kelompok ibu yang memiliki 1-2 anak dengan ibu yang memiliki 3-4 anak. Hal ini dikarenakan jumlah anak yang dimiliki tidak akan menjadi beban bagi kaum ibu jika kaum ibu mampu membangun hubungan yang baik dengan semua anak-anaknya dan bisa berbagi tanggung jawab dengan suami. Berbagi tanggung jawab dengan suami akan meringankan beban perkerjaan bagi kaum wanita dan dapat mengurangi timbulnya depresi (Bird dalam Matlin, 2012). Jumlah anak tidak memengaruhi psychological well-being juga dikarenakan dengan mengasuh anak dan mendidik anak-anak, kaum ibu mampu menunjukkan perannya dalam keluarga. Kaum ibu juga menunjukkan tingkat penguasaan lingkungan dan otonomi karena bahwa ia mampu mengatasi situasi yang kompleks yakni, mengasuh anak-anak, mengerjakan pekerjaan rumah tangga dan kegiataan lainnya.

Banyak faktor yang memengaruhi pencapaian psychological well-being, seperti tingkat pendidikan individu. Penelitian menunjukkan wanita yang memiliki pendidikan tinggi, juga memiliki tingkat kesejahteraan yang tinggi (Ryff, Magee, Kling, \& Wing, dalam Synder \& Lope, 2005). Analisis data tambahan pada penelitian ini menunjukkan hasil yang berbeda, yakni tidak ada perbedaan tingkat psychological wellbeing pada kelompok ibu yang berpendidikan dasar (SMA/SMK sederajat) dengan kelompok ibu yang berpendidikan tinggi (diploma, $\mathrm{S} 1$, dan $\mathrm{S} 2$ ).

Hasil uji beda juga dilakukan pada kelompok ibu yang usia pernikahannya memiliki rentang 1-10 tahun dengan rentang usia pernikahan 11-22 tahun. Hasil uji beda tersebut menunjukkan terdapat perbedaan tingkat psychological wellbeing pada ibu yang usia pernikahan 1-10 tahun dengan ibu yang usia pernikahan 11-22 tahun. Pada hasil uji beda, juga dapat dilihat nilai mean pada masing-masing kelompok.
Kelompok ibu yang usia pernikahan 11-22 tahun memiliki nilai mean yang lebih besar yakni 92.65 daripada kelompok ibu yang usia pernikahannya 1-10 tahun dengan mean sebesar 90.84. Hal ini menunjukkan bahwa tingkat psychological wellbeing ibu yang usia pernikahan 11-22 tahun lebih tinggi daripada ibu yang usia pernikahan 1-10 tahun. Hal ini dikarenakan usia pernikahan 1-10 tahun merupakan tahun periode awal pernikahan. Menurut Hurlock (1980) bahwa tahun-tahun awal suatu pernikahan ditandai dengan adanya penyesuaian diri antar pasangan, dengan keluarga pasangan, dan sering timbul ketegangan emosional. Pada periode awal pernikahan, kaum ibu akan melakukan penyesuain peran sebagai istri, dan menjadi orang tua sehingga menimbulkan ketegangan emosional. Semakin lama usia pernikahan, yakni seperti usia 11-22 tahun, kaum ibu pada umumnya sudah mampu mengetahui dan melakukan peran dengan baik karena sudah memiliki berbagai pengalaman di awal-awal tahun pernikahan. Kondisi ini membuat kaum ibu merasa sudah mampu menghadapi dan melewat berbagai situasi sulit atau adanya kemampuan penguasaan lingkungan. Kemampuan ibu melaksanakan peran dalam keluarga juga akan memunculkan penghargaan terhadap diri sendiri, sehingga membuat kaum ibu mampu mencapai tingkat psychological well-being yang lebih tinggi saat usia pernikahan 11-22 tahun.

Kelemahan pada penelitian ini adalah banyaknya aitemaitem yang gugur saat dilakukan ujicoba. Meskipun demikian, jumlah aitem yang tersisa dalam penelitian ini tetap dapat mengungkapkan perbedaan tingkat psychological well-being pada ibu rumah tangga dan ibu bekerja. Melalui prosedur analisis data penelitian maka tujuan dari penelitian ini telah tercapai, yaitu untuk mengetahui perbedaan tingkat psychological well-being pada ibu rumah tangga dengan ibu bekerja di Kabupaten Gianyar.

Berdasarkan penelitian yang telah dilakukan dan hasil analisis data dapat ditarik kesimpulan yaitu terdapat perbedaan tingkat psychological well-being yang signifikan pada ibu rumah tangga dengan ibu bekerja di Kabupaten Gianyar. Ibu bekerja mampu mencapai tingkat psychological well-being lebih tinggi, daripada ibu rumah tangga. Tidak ada perbedaan perbedaan tingkat psychological well-being berdasarkan jumlah anak dan tingkat pendidikan. Terdapat perbedaan tingkat psychological well-being berdasarkan usia pernikahan. Kelompok ibu dengan usia pernikahan 11-22 tahun memiliki tingkat psychological well-being yang lebih tinggi dibandingkan kelompok ibu dengan usia pernikahan 1-10 tahun.

Berdasarkan kesimpulan tersebut, peneliti dapat memberikan saran bagi ibu rumah tangga dan ibu bekerja untuk dapat mempertahankan psychological well-being yang tergolong tinggi, yaitu dengan cara memiliki harga diri yang baik. Harga diri yang baik dapat dimiliki dengan cara bersyukur terhadap semua kelebihan dan kekurangan yang 
dimiliki dan memiliki keyakinan bahwa ibu mampu menangani berbagai tugas dalam kehidupan sehari-hari. Bagi keluarga diharapkan tetap memberikan dukungan sosial terhadap kaum ibu, baik ibu rumah dan ibu bekerja. Hal ini dikarenakan kondisi keluarga mampu mempengaruhi kesejahteraan kaum ibu, seperti adanya tingkat psychological well-being yang bervariasi berdasarkan usia pernikahan. Dukungan sosial yang diberikan oleh anggota keluarga dapat berupa perhatian maupun penghargaan atas kemampuan kaum ibu melaksanakan tugas sehari-hari, baik tugas rumah tangga maupun pekerjaan.

Bagi peneliti selanjutnya diharapkan dapat melakukan penelitian serupa kepada kelompok usia lainnya seperti usia dewasa madya karena pencapaian psychological well-being dipengaruhi oleh usia, yakni semakin bertambahnya usia akan ada peningkatan dalam aspek tertentu, seperti aspek otonomi dan penguasaan lingkungan. Pada masa dewasa madya ditandai dengan adanya tuntutan untuk mempertahankan pekerjaan dan memelihara rumah tangga sehingga pada usia dewasa madya banyak perempuan yang masih berperan sebagai ibu bekerja dan ibu rumah tangga. Peneliti selanjutnya dapat melakukan penelitian serupa pada daerah Bali yang memiliki karakteristik berbeda dengan Kabupaten Gianyar, sehingga dapat diketahui apakah ada perbedaan pencapaian psychological well-being pada daerah yang memiliki adat istiadat yang mewajibkan kaum perempuan untuk berperan aktif dalam aspek sosial dengan daerah yang memiliki adat istiadat bagi kaum perempuan untuk berperan fleksibel dalam aspek sosial.

\section{DAFTAR PUSTAKA}

Atmaja, W. S., \& Virnayanthi, N. P. (2010). Mengenal Sepintas Budaya Bali. Jakarta: PT Mitra Aksara Panaitan.

Badan Pusat Statistik (2010). Penduduk Menurut Wilayah, Jenis Kelamin, dan Status Migrasi Seumur Hidup SP2010 Provinsi Bali. Bali: Badan Pusat Statistik Provinsi Bali.

Badan Pusat Statistik Provinsi Bali. (2011). Keadaan Ketenagakerjaan di Provinsi Bali/ Labor Force Situation in Bali Province Agustus/ August 2011. Bali: Bidang Statistik Sosial BPS Provinsi Bali

Barnhouse, R. T. (1994). Identitas Wanita Bagaimana Mengenal dan Membentuk Citra Diri. Yogyakarta: Penerbit Kanisius.

Compton, W. C. (2005). Introduction to Positive Psychological. United States of America: Thomson Wadsworth.

Febrida, M. (2014, April). Ibu Bekerja Tidak Lagi Merasa Bersalah Jauh Saat dari Anak. Liputan6.com. Diunduh dari http://health.liputan6.com/read/2036620/ibupekerja-tak-lagi-merasa-bersalah-saat-jauh-darianak 14 November 2014
Handayani, W. \& Abbdinnah, F. (2012, Mei). Stress Mana, Menjadi Ibu atau Wanita Karir?. Diunduh dari http://m.life.viva.co.id/news/read/316215-stressmana--menjadi-ibu-atau-wanita-karir / 20 November 2014

Harmandini, F. (2012, Februari). 5 Alasan Perlu Jadi Ibu Rumah Tangga. (Dini, Ed). Kompas.com. Diunduh dari http://female.kompas.com/read/2012/02/01/1229 1736/5.Alasan.Perlu.Jadi.Ibu.Rumah.Tangga 5 Desember 2014

Hurlock, E. B. (1980). Psikologi Perkembangan Suatu Pendekatan Rentang Kehidupan (5th ed). Jakarta: Erlangga.

Irawati, I. (2012). Hubungan antara Parenting Self-Efficacy dengan Psychological Well-Being Ibu dari Anak Usia Kanak-Kanak Madya dengan Gangguan Pendengaran. Fakultas Psikologi, Universitas Indonesia, Jakarta.

Lubis, N. L. (2013). Psikologi Kespro Wanita \& Perkembangan Reproduksinya. Jakarta: Kencana Prenada Media Group.

Matlin, M. W. (2012). Psychology of women (7th ed). USA: Wadsworth.

Ryff, C. D. (1989). Happiness Is Everything, or Is It? Explorations on. Journal of Personality and Social Psychology, 57 (6),1069-1081.

Ryff, C. D. (1995). Psychological Well-Being in Adult Life. Current Directions in Psychological Science, 4 (4), 99-104

Santrock, J. W. (2002). Life-Span Development Perkembangan Masa Hidup (5th., Vol. 2). Jakarta: Erlangga.

Singh, K., Mohan, J., \& Anasseri, M. (2012). Psychological Well-Being: Dimensions, Measurements and Applications. Germany: LAP LAMBERT Academic Publishing.

Surpha, I. W. (2002). Seputar Desa Pakraman dan Adat Bali. Bali: BP

Susanti. (2012). Hubungan Harga Diri dan Psychological Well-Being Pada Wanita Lajang Ditinjau dari Bidang Pekerjaan . Jurnal Ilmiah Mahasiswa Universitas Surabaya , 1(1).

Snyder, C. R. \& Lopez,. S. J. (2005). Handbook Of Positive Psychology. New York: Oxford University Press. 